\title{
Determining the Concept of Organic Agriculture Perceptions of Pre-service Classroom and Science Teachers Using Phenomenographic Method
}

\author{
Tülay Dizikisa ${ }^{1} \&$ Pınar Ural Keleş2,* \\ ${ }^{1}$ Ağrı Vocational Training School, Ağrı İbrahim Çeçen University, Turkey \\ ${ }^{2}$ Faculty of Education, Education of Math and Science, Department of Science Education. Ağrı İbrahim Çeçen \\ University, Turkey \\ *Correspondence: Faculty of Education, Education of Math and Science, Department of Science Education, Ağr1 \\ İbrahim Çeçen University, Turkey. Tel: 90-0472-216-2035. E-mail: pukeles@yahoo.com
}

This study was presented an oral presentation in International Conference on Advances in Natural and Applied Sciences (ICANAS 2017) which was held in 18-21 April, 2017.

Received: December 24, 2018

Accepted: January 26, 2019 Online Published: February 20, 2019

doi:10.5430/wje.v9n1p188

URL: https://doi.org/10.5430/wje.v9n1p188

\begin{abstract}
This study was carried out to determine the perceptions of pre-service classroom and science teachers related to the concept of organic agriculture. The sample of the study consisted of 85 pre-service teachers, 57 from the Department of Classroom Teaching and 28 from the Department of Science Teaching in Ağrı İbrahim Çeçen University, in the academic year of 2016-2017. In the study, a semi-structured questionnaire which includes the statement "To me, organic agriculture means......" was used as data collection tool. In this study, the organic agriculture perceptions of the pre-service teachers were determined under five main categories. The ratio of 'natural agriculture, which has the highest percentage among these categories, is $41 \%$ among the pre-service classroom teachers while this ratio is $65 \%$ among pre-service science teachers. It is among the recommendations of the study that the subjects related to organic agriculture are removed from the elective courses and placed in the science curriculum.
\end{abstract}

Keywords: pre-service classroom teacher, organic agriculture concept, phenomenographic research

\section{Introduction}

Agriculture is an indispensable element of society's basic needs, especially for nutrition. 'Agriculture', which is considered to be one of the applied sciences in the present day, can be defined as the most general form of activities to obtain herbal and animal products (MEB, 2015). After the World War II, the agricultural sector has had its share from the rapid technological developments. Soil, water and air are contaminated, and the food produced by using various chemical drugs and fertilizers have caused serious health problems in humans (Ak, 2004; Kilcher, 2007). The conscious producers and consumers gathered together and developed the concept of organic agriculture for the elimination of these emerging problems and the production and consumption of healthier products (Öztürk, 2004).

Organic agriculture "includes human-friendly and environment-friendly production systems to restore the natural balance that has been lost as a result of faulty practices in the ecological system, and it recommends the use of organic and green fertilization, alternation, soil conservation, plant resistance, parasites and predators instead of synthetic chemical drugs and fertilizers and it is a production method that takes the principle of increasing the quality of the product, not the quantity increase in production" (Rehber and Turhan, 2001; Kilcher, 2007). The definition of organic agriculture, approved by the International Federation of Organic Agriculture Movements (IFOAM) in Italy in 2018, is that "Organic agriculture is a production system that sustains the health of soils, ecosystems and people." This system is seen as an approach based on sustainable agricultural systems with its own specific principles and practices in the period from the upbringing of organic products to the sale of their products (Demiryürek, 2004). Organic agriculture is not only a source of food production, but it is also sustainable agriculture and development, eco-tourism, preserves 
biodiversity, and it enables the elimination of the effects of erosion, desertification and climate change factors (Özbağ, 2010).

Nowadays, with the increasing level of education, the increase in the level of environment and health awareness leads to an increase in the demand for organic agricultural products (Vatansever Deviren \& Çelik, 2017). Therefore, organic agriculture practices are widespread in many countries. According to 2015 data, 50.9 million hectares around the world are organic agriculture. This constitutes $1.1 \%$ of the total agricultural field (FIBL and IFOAM, 2017). According to 2012 data, the largest organic food market in the world is in the US (Bilen et al., 2012). Other important countries in the world organic food market are Japan and Australia. The main countries in the European organic food market are Germany, France and the UK (Willer \& Klicher, 2011). In Turkey, organic agriculture has developed rapidly in the last 20 years. In the country, the number of crops increased by $42 \%$, production area by $837 \%$ and production by $430 \%$ in organic agriculture between 2002-2014 (GTHB, 2016). As a result of these developments, Turkey has become one of the major countries that export organic food to EU. Moreover, Turkey, due to its climate and soil conditions are favorable and with its more biological and genetic diversity, is a suitable country for organic agriculture system. Therefore, its potential for organic agriculture is very high (Merdan \& Kaya, 2013). These make the concept of organic agriculture important for Turkey and the countries in the world.

In the rapidly developing and changing world, education systems also need to constantly improve themselves in parallel with these developments. In this direction, educational programs in many countries are subject to changes in line with the needs of the day (İyibil \& Sağlam Arslan, 2010). In this context, $3^{\text {rd }}-8^{\text {th }}$ grades science curriculum was updated in 2017 in Turkey. However, in the previous curriculum of the science course, while the acquisitions of the organic agriculture concept were included, the acquisitions related to the subject in the 2017 science curriculum were removed and instead, the acquisitions of "local and global environmental problems" were added (MEB, 2017). The subjects of organic agriculture and socio-scientific subjects are given within the scope of "elective environmental education" (MEB, 2015). However, it is a known fact that elective courses are not selected according to the students' will, and teaching of the other courses are usually conducted in selected elective courses (Öner, 2015; Ural Keleş et al., 2016). It is obvious that this will cause significant problems in the subject of "training all individuals as science literate", which is the basic vision of science course. In France, however, organic agriculture has taken its place in the science program from the primary school third grade. At the sixth grade, this subject is under a separate section as practice-oriented (Duco, 2008, p. 173).

On the other hand, it has been determined that the number of studies on the subject is quite limited. In the study conducted with secondary school students by Akyol and Çam (2014), it was stated that the activities related to the subject helped the students understand the importance of organic agriculture and help to eliminate their misconceptions about the subject. In another study conducted by Toraman (2013), it was reported that students developed awareness related to the importance of organic agriculture. Çavuş (2013) found that the students who have advanced epistemological beliefs have more comprehensive opinions about organic agriculture concept compared to the students who have undeveloped epistemological beliefs. In another study conducted by Ülger (2009), it is stated that in the science and technology curriculum of primary education, the acquisitions and activities allocated to organic agriculture are insufficient and this is tried to be balanced with the Elective Agriculture course. In another study conducted by Çeken (2010), it is emphasized to what extent "Organic agriculture" is included in elementary Science and Technology curriculum, and it was determined that the subject does not have enough variety of activities in terms of student centered applications and does not comply with the concept of spiral model. In their study, Warnick, Thompson and Gummer (2004) stated that it is necessary to integrate the subjects related to agriculture and especially organic agriculture in science courses.

On the other hand, the role of teachers in the success of education and training activities is a well-known fact. Therefore, it is very important that pre-service teachers understand the concepts of their fields correctly as well as they are equipped with general culture, profession and field knowledge. However, there is no study conducted with pre-service teachers and teachers in the literature mentioned above. For this reason, it is a key concern how the concept of organic agriculture, which is becoming more and more popular, is perceived by pre-service teachers who are going to be science and class teachers and the instructors of science courses. From this point of view, the aim of this study is to determine the perceptions of the pre-service teachers related to organic agriculture concept. 


\section{Method}

\subsection{Research Method}

In this study, phenomenology method, among qualitative research methods, is used (Çepni, 2012). In the phenomonographic studies, the perceptions about the concepts and events are revealed realistically and wholly in a natural environment (Yıldırım \& Şimşek, 2006). Phenomenographic research is concerned with what people perceive, understand and experience about the phenomena they encounter in the universe they live in. The definitions of the individuals related to the phenomenon is not considered to be true or false in phenomenographic research. The definitions of individuals related to the phenomenon to be researched (such as learning and teaching) are categorized. The categorization of definitions makes it clear what individuals think (Koballa, Graber, Coleman, \& Kemp, 2000).

\subsection{Sample of the Research}

The sample of the study consists of 85 pre-service teachers, 57 from the department of Classroom Teaching and 28 from the department of Science Teaching, from Ağrı İbrahim Çeçen University in 2016-2017 academic years.

\subsection{Data Collection Tool}

Pre-service classroom and science teachers are given a semi-structured protocol in order to determine how they perceive the concept of organic agriculture. This form includes the statement "To me, organic agriculture means ....." The pre-service teachers were given 5 minutes to respond to this statement with their handwriting, and the definitions were the main data source of the research.

\subsection{Data Analysis}

The data obtained from the study were analyzed with phenomenological analysis method. In the study, the expressions were first put into black and white and then were divided into temporary pre-categories. Thanks to the preliminary category, complex and complicated views were made clear and understandable. The preliminary category was reviewed for the second time and the perception categories were created and the expressions included in these categories were arranged. The data obtained from the study were analyzed with a field expert and a researcher. The data were coded separately by two researchers and the expressions that made up the categories and perception categories were determined. The cases in which researchers made the same coding in the coding of the data was considered as consensus and the cases in which the researchers made different coding were considered as dissidence. In cases in which one of the researchers run into a contradiction, the opinion of the other researcher was taken, and the coding was done accordingly. The reliability of the data analysis in the study was calculated by using the Reliability = Consensus / (Consensus + Opinion) formula (Miles \& Huberman, 1994). The mean reliability of the coders for this study was $86 \%$. Research is accepted as reliable if the reliability calculations are above $70 \%$ (Miles \& Huberman, 1994). The answers of some students were included in more than one category (Aydin, 2010; Çekmez, Yildız, \& Bütüner, 2012).

The data obtained as a result of analyzes are presented in tables by calculating percentage and frequencies for pre-service science and classroom teachers.

\section{Findings}

In the study, in the analysis of the responds of the pre-service teachers to the statement "To me, organic agriculture means......", "natural agriculture", "agriculture without the use of chemical agents", "agriculture without the use GMO", "healthy agriculture" and "healthy future" categories were obtained. In this section, the expressions in these five categories and their distributions in pre-service classroom and science teachers by calculating the percentages and frequencies. In Table 1 below, the category of "natural agriculture" and the expressions in this category are indicated.

It is the first category which has the highest percentage related to natural agriculture category among the perception categories generated from the responses of pre-service Classroom and Science teachers and consists of 6 different expressions. When the Table 1 is examined, it is seen that the ratio of science pre-service science teachers' expressions in this category is $65 \%$, however, the ratio of the pre-service classroom teachers in this category is $41 \%$. The expression, which has the highest percentage among the teachers, is the expression of "natural agriculture" While the ratio of this expression in pre-service science teachers is $25 \%$, it is $14 \%$ in pre-service classroom teachers. While the expression of "primitive agriculture" (14\%) was observed only in pre-service classroom teachers, "naturality" (11\%) was found only in pre-service science teachers. 
Table 1. "Natural agriculture" Perception Category Generated from Pre-service Classroom and Science Teachers' Responses and the Distribution of the Expressions

\begin{tabular}{|c|c|c|c|c|c|}
\hline \multirow{2}{*}{$\begin{array}{l}\text { Perception } \\
\text { Categories }\end{array}$} & \multirow[t]{2}{*}{ Expressions } & \multicolumn{2}{|c|}{$\begin{array}{l}\text { Pre. Sci T.* } \\
\quad \mathrm{N}=28\end{array}$} & \multicolumn{2}{|c|}{$\begin{array}{c}\text { Pre Class. T.** } \\
\mathrm{N}=57\end{array}$} \\
\hline & & (f) & $(\%)$ & (f) & $(\%)$ \\
\hline \multirow{6}{*}{$\begin{array}{l}\text { "To me, organic } \\
\text { agriculture means } \\
\text { natural agriculture }\end{array}$} & $\begin{array}{l}\text { Agriculture done in natural environment and in the } \\
\text { appropriate season }\end{array}$ & 5 & 18 & 1 & 2 \\
\hline & $\begin{array}{l}\text { It is the agriculture that its soil, water and fertilizer in which } \\
\text { there is nothing unnatural }\end{array}$ & 2 & 7 & 5 & 9 \\
\hline & Agriculture done without interfering its soil fertilizer & 1 & 4 & 1 & 2 \\
\hline & Natural agriculture & 7 & 25 & 8 & 14 \\
\hline & Naturality & 3 & 11 & - & - \\
\hline & Primitive agriculture & - & - & 8 & 14 \\
\hline Total & & 18 & 65 & 23 & 41 \\
\hline
\end{tabular}

${ }^{*}$ Pre-service Science teachers, ${ }^{* *}$ Pre-service Classroom teachers.

Table 2 below indicates the perception category of "agriculture without the use of chemical agents" and the distribution of the expressions in this category.

Table 2. "Agriculture without the use of chemical agents" Perception Category Generated from Pre-service Classroom and Science Teachers' Responses and the Distribution of the Expressions in This Category

\begin{tabular}{llcccc}
\hline \multirow{2}{*}{$\begin{array}{l}\text { Perception } \\
\text { Categories }\end{array}$} & Expressions & \multicolumn{2}{c}{$\begin{array}{c}\text { Pre. Sci T.* } \\
\text { N=28 }\end{array}$} & \multicolumn{2}{c}{$\begin{array}{c}\text { Pre Class. T.** } \\
\text { N=57 }\end{array}$} \\
\cline { 3 - 6 } & & (f) & $\mathbf{( \% )}$ & (f) & (\%) \\
\hline "To me, organic & Agriculture without hormones and pesticides & 3 & 11 & 7 & 12 \\
agriculture means the & Agriculture without chemical fertilizers & 1 & 4 & 1 & 2 \\
agriculture in which & Agriculture without pesticides & 4 & 14 & 4 & 7 \\
chemical agents are & Agriculture without chemical additives & 5 & 18 & 3 & 5 \\
not used." & Additive-free agriculture & - & - & 4 & 7 \\
Total & & $\mathbf{1 3}$ & $\mathbf{4 7}$ & $\mathbf{1 9}$ & $\mathbf{3 3}$ \\
\hline
\end{tabular}

* Pre-service Science teachers, ${ }^{* *}$ Pre-service Classroom teachers.

The perception category of "agriculture without the use of chemical agents" is the second category which has the highest percentage and it consists of 5 different expressions. When the Table 2 is examined, it is seen that the ratio of science pre-service science teachers' expressions in this category is $47 \%$, however, the ratio of the pre-service classroom teachers in this category is $33 \%$. The expression, which has the highest percentage $(18 \%)$ among the pre-service science teachers, is the expression of "Agriculture without chemical additives." And the expression "Agriculture without hormones and pesticides" has the highest rate (14\%) among the pre-service classroom teachers. It can be seen in Table 2 that the expression "Additive-free agriculture" is the expression of only the pre-service classroom teachers $(7 \%)$ in this category.

Table 3 below indicates the perception category of "Agriculture without the use of GMO" and the distribution of the expressions in this category.

The perception category of "Agriculture without the use of GMO " is the third category among the perception categories and consists of 4 different expressions. When the Table 3 is examined, it is seen that the ratio of science pre-service science teachers' expressions in this category is $47 \%$, however, the ratio of the pre-service classroom teachers in this category is $21 \%$. The expression, which has the highest percentage (18\%) among the pre-service science teachers, is the expression of "Agriculture with natural seeds." And the expression "GMO-free agriculture" has the highest rate (12\%) among the pre-service classroom teachers. 
Table 3. "Agriculture without the use of GMO" Perception Category Generated from Pre-service Classroom and Science Teachers' Responses and the Distribution of the Expressions in This Category

\begin{tabular}{|c|c|c|c|c|c|}
\hline \multirow{2}{*}{ Perception Categories } & \multirow{2}{*}{ Expressions } & \multicolumn{2}{|c|}{$\begin{array}{l}\text { Pre. Sci. T. } \\
\quad \mathrm{N}=28\end{array}$} & \multicolumn{2}{|c|}{$\begin{array}{l}\text { Pre Class. T. } \\
\text { N=57 }\end{array}$} \\
\hline & & (f) & $(\%)$ & (f) & $(\%)$ \\
\hline "To me, organic & GMO-free agriculture & 3 & 11 & 7 & 12 \\
\hline agriculture means the & Agriculture with the genetically unmodified seeds & 1 & 4 & 3 & 5 \\
\hline agriculture in which & Genetically unmodified product & 4 & 14 & 1 & 2 \\
\hline GMO is not used." & Agriculture with natural seeds & 5 & 18 & 1 & 2 \\
\hline Total & & 13 & 47 & 12 & 21 \\
\hline
\end{tabular}

* Pre-service Science teachers, ${ }^{* *}$ Pre-service Classroom teachers.

Table 4 below indicates the perception category of "healthy agriculture" and the distribution of the expressions in this category.

Table 4. "Healthy agriculture" Perception Category Generated from Pre-service Classroom and Science Teachers' Responses and the Distribution of the Expressions in This Category

\begin{tabular}{|c|c|c|c|c|c|}
\hline \multirow{2}{*}{$\begin{array}{l}\text { Perception } \\
\text { Categories }\end{array}$} & \multirow[t]{2}{*}{ Expressions } & \multicolumn{2}{|c|}{$\begin{array}{l}\text { Pre. Sci. T. } \\
\mathrm{N}=28\end{array}$} & \multicolumn{2}{|c|}{$\begin{array}{l}\text { Pre Class. } \\
\mathrm{T}^{* *} \mathrm{~N}=57\end{array}$} \\
\hline & & (f) & $(\%)$ & (f) & $(\%)$ \\
\hline \multirow{3}{*}{$\begin{array}{l}\text { To me, organic } \\
\text { agriculture means } \\
\text { healthy agriculture }\end{array}$} & Healthy foods & 6 & 22 & 2 & 4 \\
\hline & $\begin{array}{l}\text { Agriculture without harming the humans and } \\
\text { the environment }\end{array}$ & - & - & 1 & 2 \\
\hline & Healthy agriculture & - & - & 10 & 18 \\
\hline Total & & 6 & 22 & 13 & 24 \\
\hline
\end{tabular}

*Pre-service Science teachers, ${ }^{* *}$ Pre-service Classroom teachers.

The perception category of "Healthy agriculture" is the fourth category among the perception categories and consists of 3 different expressions. When the Table 4 is examined, it is seen that the ratio of science pre-service science teachers' expressions in this category is $22 \%$, however, the ratio of the pre-service classroom teachers in this category is $24 \%$. The expression, which has the highest percentage $(22 \%)$ among the pre-service science teachers, is the expression of "Healthy foods." And the expression "Healthy agriculture" has the highest rate (18\%) among the pre-service classroom teachers.

The perception category of "healthy future" and the distribution of the expressions in this category are indicated in Table 5 below.

Table 5. "Healthy Future" Perception Category Generated from Pre-service Classroom and Science Teachers' Responses and the Distribution of the Expressions in This Category

\begin{tabular}{llcccc}
\hline \multirow{2}{*}{$\begin{array}{l}\text { Perception } \\
\text { Categories }\end{array}$} & Expressions & \multicolumn{2}{c}{$\begin{array}{c}\text { Pre. Sci. T. } \\
\text { N=28 }\end{array}$} & \multicolumn{2}{c}{$\begin{array}{c}\text { Pre Class. T.* } \\
\text { N=57 }\end{array}$} \\
\cline { 3 - 6 } & & (f) & $\mathbf{( \% )}$ & (f) & (\%) \\
\hline "To me, organic & Healthy future & 4 & 14 & - & - \\
agriculture means & Outliving & 4 & 14 & 2 & 4 \\
healthy future" & Healthy outliving & - & - & 4 & 7 \\
Total & & $\mathbf{8}$ & $\mathbf{2 8}$ & $\mathbf{6}$ & $\mathbf{1 1}$ \\
\hline
\end{tabular}

** Pre-service Science teachers, ${ }^{* *}$ Pre-service Classroom teachers.

The perception category of "Healthy future" is the fifth category among the perception categories and consists of 3 different expressions. When the Table 5 is examined, it is seen that the ratio of science pre-service science teachers' expressions in this category is $28 \%$, however, the ratio of the pre-service classroom teachers in this category is $11 \%$. The expression, which has the highest percentage (14\%) among the pre-service science teachers, is the expression of "Healthy future" and "Outliving" And the expression "Healthy outliving" has the highest rate (7\%) among the 
pre-service classroom teachers while this was not expressed by pre-service science teachers.

\section{Discussion and Results}

In the study conducted to determine the perceptions of the pre-service science and classroom teachers related to organic agriculture concept, five perception categories related to the concept of organic agriculture were obtained although their rates were different. These are the categories of "natural agriculture", "agriculture without the use of chemical agents", "agriculture without the use GMO", "healthy agriculture" and "healthy future." In this study, the category with the highest ratio among the categories which are formed from the responds of both pre-service classroom and science teachers is the category of "natural agriculture". While the ratio of pre-service science teachers' expressions in this category is $65 \%$, it is seen that the ratio of the pre-service classroom teachers' expressions in this category is $41 \%$ (Table 1). In the study, the second category with the second highest ratio among the pre-service branch teachers is the category of "agriculture without the use of chemical agents." While the ratio of pre-service science teachers' expressions in this category was $47 \%$, the percentage of the expressions of the pre-service classroom teachers was $33 \%$ (Table 2). Based on these data, it can be said that both pre-service classroom and science teachers mostly perceive the concept of organic agriculture as "natural agriculture" and this is followed by the perception of "agriculture without chemical agents" (Table 1,2). In the study conducted by Toraman (2013) in the literature, it is stated that students express organic agriculture as "natural and reliable agriculture" In the same study, it is reported that the expression "not containing chemical substances" is among the other statements that students use to describe the concept of organic agriculture. In the study conducted by Çavuş (2013) with 8th grade students, it is reported that the students who have developed epistemological beliefs mostly define the concept of organic agriculture as "natural agriculture". On the other hand, Demiryürek (2011) emphasizes that organic agriculture is not entirely natural agriculture and that organic agriculture can be seen as an approach towards sustainable agriculture systems with its own special principles and practices in the period from the cultivation of organic products to the sale of the products. In the same study, the definitions related to organic agriculture often emphasize the prohibition or limitation of the use of chemical, soluble and inorganic substances such as pesticides, fertilizers, growth regulators and animal hormones.

Another result of the study was that the rate of the pre-service science teachers was higher than the rate of pre-service classroom teachers in terms of "natural agriculture" and "agriculture without chemical agents" (Table 1,2). This is thought to cause some problems. Because the primary school courses carried out by the primary school classroom teachers in the $3^{\text {rd }}$ and 4rd grade science classes are the first time that students meet with science subjects, and they have an important place in their cognitive and affective learning. Therefore, it is very important for the classroom teachers who carry out these courses to perceive the concepts related to their field completely and clearly as well as being fully equipped with the knowledge of the field (Ünişen \& Kaya, 2015; Tüysüz \& Balıkçı, 2016).

In the study, the other perceptions of the pre-service science teachers related to the concept of organic agriculture are "agriculture without the use of GMO (47)", "healthy future (28)", "healthy agriculture (22)", respectively. In pre-service classroom teachers, this is "healthy agriculture (24)", "agriculture without the use of GMO (21)" and "healthy future (11)", respectively. Similar results are found in the literature limited to the subject. Ülger (2009), using the interview technique with 94 students from $6^{\text {th }}, 7^{\text {th }}$ and $8^{\text {th }}$ grades, stated that $95 \%$ of the students stated organic agriculture is a healthy method. In the study by Çavuş, (2013), it is stated that 8th grade students with developed epistemological beliefs have the idea that organic agriculture cannot be done with GMO compared to the students who have undeveloped epistemological beliefs. In the action research conducted by Toraman (2013), it is emphasized that students had difficulty in explaining the importance of organic agriculture before the application, and the students expressed organic agriculture as natural, healthy, environmentalist and reliable after the application. Therefore, it is thought that the fact that pre-service science teachers' perceptions about the concept of organic agriculture have different proportions from the pre-service classroom teachers can be derived from different courses taken in parallel with the subject of organic agriculture at the undergraduate level.

\section{Recommendations}

Based on the results of this study, it is thought that it is very important to include the courses related to the socio-scientific subjects in which the subject of organic agriculture is included in both pre-service classroom and science teachers' curriculum. On the other hand, the subject of organic agriculture should be included more in the subject of "Special Topics in Biology" which is taught in the department of science teaching, and enriching the course with applications, activities and projects related to the subject may allow pre-service teachers to graduate from the department more equipped. In addition, it can increase the awareness of our children about this important subject by 
removing the subjects of organic agriculture from the elective courses and putting them in the science curriculum.

\section{References}

Ak, İ. (2004). Apolyont doğal tarım ve hayvancılık projesi. I. Uluslararası organik hayvansal üretim ve gida güvenliği kongresi, 28 Nisan-1 Mayıs, 144.

Akyol, T., \& Çam, A. (2014). Bilimin doğasına yönelik bir etkinlik örneği: organik tarım neden önemli? Araştırma Temelli Etkinlik Dergisi, 4(1), 1-11.

Aydin, F. (2010). Secondary school students perceptions towards global warming: A phenomenographic analysis. Scientific Research and Essays, 5(12), 1566-1570.

Bilen, E., Çiçekli, Ö., Aksoy, U., \& Altindisli, A. (2012). Dünya ve Türkiye'de organik tarım. İmak Ofset. pp. 8-37.

Çavuş, R. (2013). Farklı epistemolojik inanışlara sahip 8. sınıf öğrencilerinin sosyo bilimsel konulara bakış açıları. Sakarya Üniversitesi, Eğitim Bilimleri Enstitüsü, İlköğretim Anabilim Dalı, Fen Bilgisi Eğitimi Bilim Dalı, Yüksek Lisans Tezi.

Çeken, R. (2010). Organik tarımın ilköğretim fen ve teknoloji programındaki yeri. Çankırı Karatekin Üniversitesi SBE Dergisi, 2, 33-42.

Çekmez, E., Yıldız, C., \& Bütüner, S. Ö. (2012). Phenomenographic research method. Balıkesir Üniversitesi Necatibey Eğitim Fakültesi Elektronik Fen ve Matematik Ĕ̈itimi Dergisi, 6(2), 77-10.

Çepni, S. (2012). Araştırma ve proje çalışmalarına giriş. Geliştirilmiş 6. Baskı. s. 76. Ankara.

Demiryürek, K. (2004). Dünya ve Türkiye'de organik tarım. Harran Üniversitesi, Ziraat Fakültesi Dergisi, 8(3-4), 63-71.

Demiryürek, K. (2011). Organik tarım kavramı ve organik tarımın Dünya ve Türkiye'deki durumu. GOÜ, Ziraat Fakültesi Dergisi, 28(1), 27-36.

Duco, A. (2008). Sciences de la Vie et de la Tere-3e. Paris: Belin.

FIBL \& IFOAM. (2017). The world of organic agriculture statistics and emerging trends. Retrieved from http://www.organcworld.net/yearbook/yearbook-2017.html. 05.05.2018

GTHB. (2016). TC Gıda Tarım ve Hayvancılık Bakanlığı Tarımsal Destekler. Retrieved 05.05.2018 from https://www.tarimorman.gov.tr/SGB/TARYAT/Belgeler/tar\%C4\%B1msal\%20destekler.pdf

IFOAM, (2018). Definition of organic farming. Retrieved 05.05.2018 from http://www.ifoam.org/growing_organic/definitions/sd hw/pdf/DOA_Turkish.pdf

İyibil, Ü., \& Sağlam Arslan, A. (2010). Fizik öğretmen adaylarının yıldız kavramına dair zihinsel modelleri. Necatibey Eğitim Fakültesi Elektronik Fen ve Matematik Eğitimi Dergisi (EFMED), 2(4), 25-46.

Kilcher, L. (2007). How organic farming contributes to sustainable development. JARTS Witzenhausen, Supplement, 89, 31-49.

Koballa, T., Graber, W., Coleman, C., \& Kemp, C. (2000). Prospective gymnasium teachers conceptions of chemistry learning and teaching. International Journal of Science Education, 22(2), 209-224. https://doi.org/10.1080/095006900289967

MEB. (2015). T.C. Millî Ĕ̆itim Bakanlı̆ğ, talim terbiye kurulu başkanlı̆ğ, ortaokul çevre eğitimi dersi. öğretim program1, Ankara.

MEB. (2017). T.C. Millî Ĕgitim Bakanlı̆̆ı, Fen bilimleri dersi öğretim programı (İlkokul ve Ortaokul 3, 4, 5, 6, 7 ve 8. Siniflar). Ankara.

Merdan, K., \& Kaya, V. (2013). Türkiye'deki organik tarımın ekonomik analizi, Atatürk Üniversitesi Sosyal Bilimler Enstitüsü Dergisi, 17(3), 239-252.

Miles, M. B., \& Huberman, A. M. (1994). Qualitative data analysis: An expanded sourcebook (2nd ed.). Thousand Oaks, California: SAGE.

Öner, A. (2015). Seçmeli bilim uygulamaları dersinin 7. sını ögrencilerin fen ve teknoloji dersindeki BSB, tutum ve motivasyonlarına etkisi. Ağrı İbrahim Çeçen Üniversitesi, Fen Bilimleri Enstitüsü, Yüksek Lisans Tezi, Ağrı.

Özbağ, B. C. (2010). Türkiye'de organik tarımın ekonomik analizi. Yayımlanmamış Yüksek Lisans Tezi, Uludağ 
Üniversitesi Fen Bilimleri Enstitüsü, Bursa.

Öztürk, A. İ. (2004). Türkiye'de organik bal üretimi. I. Uluslararası organik hayvansal üretim ve gıda güvenliği kongresi, 28 Nisan-1 Mayıs, 2004, s.111.

Rehber, E., \& Ş, Turhan. (2001). Prospects and challenges for developing countries in trade and production of organic food and fibers: The Case of Turkey. 72nd EAAE Seminar Organic Food and Marketing Trends, Chania, Greece, 7-10 June 2001.

Toraman, S. (2013). 6. ve 7. Sinıf ögrencilerinin fen-teknoloji-toplum-çevre ilişkilendirmelerini geliştirmeye yönelik bir eylem araştırması: çevremi eğitiyorum. Yayımlanmamış Yüksek Lisans Tezi. Sakarya Üniversitesi, Eğitim Bilimleri Enstitüsü, Sakarya.

Tüysüz, C., \& Balıkçı, Ç. (2016). Sınıf öğretmenlerinin 3. sınıf fen bilimleri dersi öğretim programına yönelik görüşleri, Mustafa Kemal Üniversitesi Sosyal Bilimler Enstitüsü Dergisi, 13(36), 169-180.

Ural Keleş, P., Haşıloğlu, M. A., Aydın, S., \& Öner, A. (2016). The impact of elective application of science lessons on sciences courses: a qualitative study of 6th grade students. Participatory educational research (PER,) Special Issue(II), 143-156. https://doi.org/10.17275/per.16.spi.2.16

Ülger, A. Ö. (2009). İlköğretim öğrencilerinin organik tarım hakkındaki görüşlerinin doğa zekâsı açısından ele alınması, Ekolojik Tarım Organizasyonu Derneği. Retrieved 21.02.2016. from www.eto.org.tr/

Ünişen, A., \& Kaya, E. (2015). Fen bilimleri dersinin ilkokul üçüncü sınıf programına alınmasıyla ilgili öğretmen görüşlerinin değerlendirilmesi, Adıyaman Üniversitesi Sosyal Bilimler Enstitüsü Dergisi, 8(20), 546-571. https://doi.org/10.14520/adyusbd.62061

Vatansever Deviren, N., \& Çelik, N. (2017). Dünya'da ve Türkiye'de organik tarımın ekonomik açıdan değerlendirilmesi. Uluslararası Sosyal Araştırmalar Dergisi, 48(10), 1307-9581.

Warnick, B. K., Thompson, G. W., \& Gummer, E. S. (2004). Perceptions of science teachers regarding the integration of science into the agricultural education curriculum. Journal of Agricultural Education, 45(1), 62-72. https://doi.org/10.5032/jae.2004.01062

Willer, H., \& L. Klicher, (eds.). (2011). The world of organic farming. Statistics and emerging trends 2011. FiBL-IFOAM Report. IFOAM, Bonn and FiBL, Fric.

Yıldırım, A., \& Şimşek, H. (2006). Sosyal bilimlerde nitel araştırma yöntemleri. Seçkin Yayınevi, Ankara. 